\title{
A new form of gastric banding
}

\author{
Paul Wolfson, Ross Sayers, Sonia Bouri, Mohamed Shariff
}

Watford General Hospital, Hertfordshire, UK

\section{Correspondence to}

Dr Paul Wolfson,

paulbwolfson@gmail.com

Accepted 27 March 2015

\section{DESCRIPTION}

A 23-year-old woman with a history of Turners mosaicism, learning difficulties and Crohn's disease

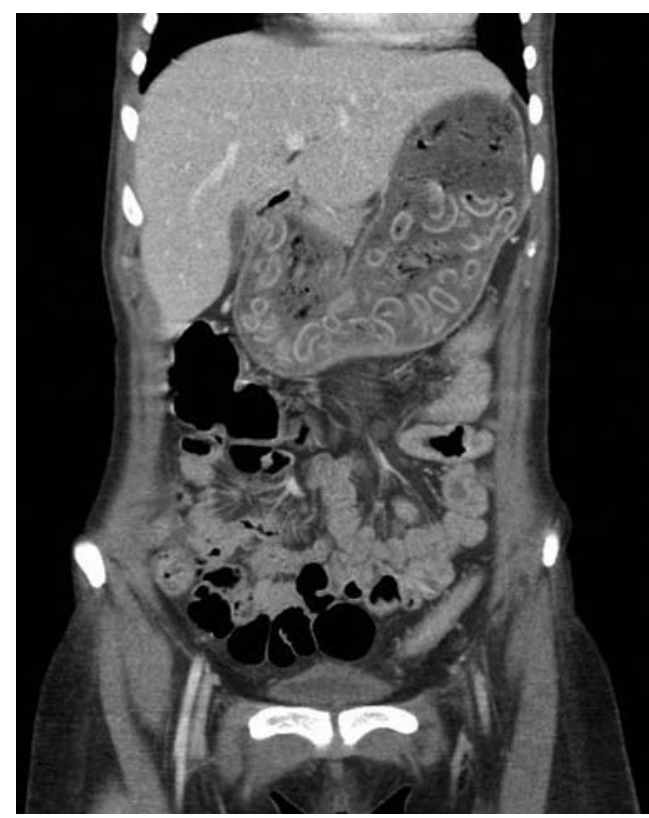

Figure 1 Abdominal CT scan showing significant gastric residue with unusual-looking gastric content.

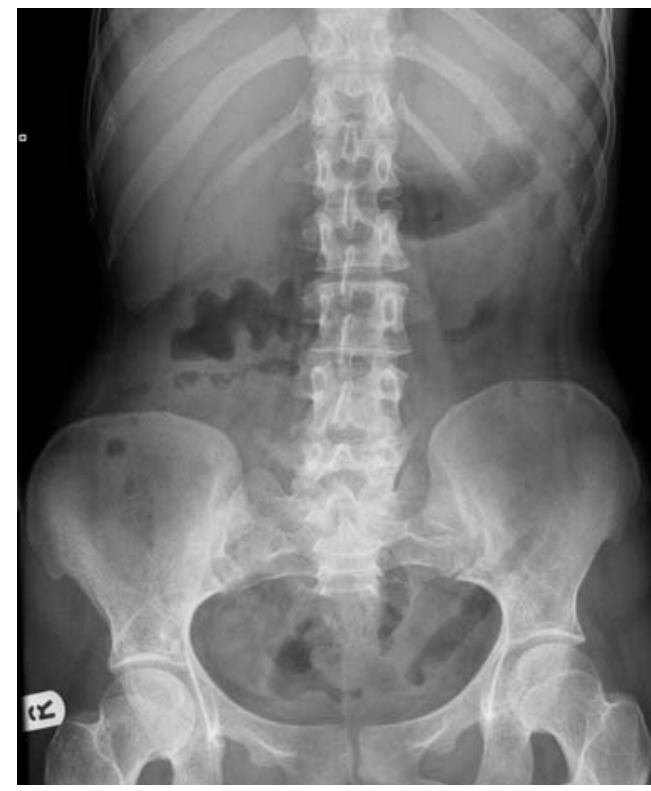

Figure 2 Plain abdominal X-ray with no significant abnormalities. presented with bloody diarrhoea and abdominal pain. Colonoscopy revealed a pancolitis with histology confirming a severe colitis with acute inflammation. A CT scan (figure 1) was requested to rule out a colonic perforation. This described 'significant gastric residue with unusual-looking gastric content'. The identity of the gastric content became apparent when the patient offered the medical staff a loom band bracelet. Of note, the stomach appeared unremarkable on a plain abdominal film (figure 2) and the abnormality was only apparent on CT scan. The consensus after multidisciplinary meeting was that the bands, which are small and flexible, were at very low risk of obstruction, ${ }^{1}$ and were allowed to pass naturally.

\section{Learning points}

- Importance of using conservative measures to manage ingested foreign bodies if less than $5 \mathrm{~cm}$ long or $3 \mathrm{~cm}$ in diameter. ${ }^{2} 3$

- Importance of a full visual survey of patients and surroundings prior to their examination.

- Illustrates difficulties of managing patients with learning difficulties on general medical wards with staff that less frequently manage such patients.

Contributors Overall supervision was provided by MS Original draft was by PW and RS, with input from SB. All authors were involved in conception, design, acquisition of the data, drafting of the article or revision for important intellectual content. Final approval of published version was from all authors.

Competing interests None declared.

Patient consent Obtained.

Provenance and peer review Not commissioned; externally pee reviewed.

\section{REFERENCES}

1 Travis SPL, Ahmad T, Collier J, et al. Pocket consultant gastroenterology. 3rd edn. Blackwell publishing, 2005.

2 Ginsberg GG. Management of ingested foreign objects and food bolus impactions. Gastrointest Endosc 1995:41:33-8.

3 Ikenberry SO, Jue TL, Anderson MA, et al. Management of ingested foreign bodies and food impactions. Gastrointest Endosc 2011;73:1085-91. 


\section{Images in...}

Copyright 2015 BMJ Publishing Group. All rights reserved. For permission to reuse any of this content visit http://group.bmj.com/group/rights-licensing/permissions.

BMJ Case Report Fellows may re-use this article for personal use and teaching without any further permission.

Become a Fellow of BMJ Case Reports today and you can:

- Submit as many cases as you like

- Enjoy fast sympathetic peer review and rapid publication of accepted articles

- Access all the published articles

- Re-use any of the published material for personal use and teaching without further permission

For information on Institutional Fellowships contact consortiasales@bmjgroup.com

Visit casereports.bmj.com for more articles like this and to become a Fellow 